\title{
Identification of bacterial pathogen associated with red stripe/top rot disease of sugarcane in Punjab, India
}

\author{
R. Yonzone ${ }^{1 *}$, B. Kumar ${ }^{2}$, P.P. Singh ${ }^{3}$, M.S. Hunjan ${ }^{3}$ and B. Das ${ }^{1}$ \\ ${ }^{1}$ College of Agriculture (Extended Campus), U.B.K.V, Majhian, Dakshin Dinajpur, 733133 (West Bengal), INDIA \\ ${ }^{2}$ Regional Research Station, Punjab Agricultural University, Kapurthala- 144601 (Punjab), INDIA \\ ${ }^{3}$ Department of Plant Pathology Punjab Agricultural University, Ludhiana-141 004 (Punjab), INDIA \\ *Corresponding author.E-mail: rakesh_yonzone@yahoo.com
}

Received: July 20, 2015; Revised received: February 26, 2016; Accepted: May 25, 2016

\begin{abstract}
This study was aim to identify the pathogen associated with the red stripe/top rot disease. The isolates were collected from major sugarcane growing districts of Punjab. Molecular identification of the pathogen was carried out to confirm the associated organism with this disease. Of the different sets of specific PCR based molecular markers were used, primer sets SeQ1 (Aaa) and SeQ2 (Aaa) amplified the expected 550bp of ITS (Internal Transcribed Spacer) region of the rDNA which revealed the pathogen as Acidovorax avenae pv. avenae, whereas the primer set Aaaf3 and Aaar2 are specific to strains that infect rice crop did not amplify any fragment. Our studies confirmed Acidovorax avenae pv. avenae as the causal bacterium associated with the red stripe/top rot of sugarcane in Punjab.
\end{abstract}

Keywords: Acidovorax avenae pv. avenae, ITS, PCR, Red stripe, Top rot.

\section{INTRODUCTION}

Sugarcane is one of the major industrial crops in India cultivated in about 5.0 million hectare under sugarcane cultivation with total production of 338.963 million tones. The demand of sugarcane is growing worldwide with the population growth and by 2030 and it is estimated that the sugar requirement will be 50 per cent higher. In Punjab it is cultivated in about 94 thousand hectare of land with an average cane production of 7.05 million tones (Anonymous, 2015).The red stripe/top rot caused by Pseudomonas rubrilineans (Lee et al., 1925) presently identified as Acidovorax avenae $p v$. avenae has become economically important disease ever since its first report in Hawaii (Lyon, 1922) and in India (McRae and Desai, 1933). As this diseases possess a constant threat to the successful cultivation of sugarcane varieties this disease could not be ignored and neglected because of their effects on the quality and/or quantity of sugarcane. An epidemic of Red stripe has been reported on Co 312 in Delhi and eastern Punjab during May and June (Chona and Rao, 1963). Since then this disease has not received any attention in our country and information's available on this disease are based on observations only. Therefore, during the present investigation an attempt has been made to identify the pathogen causing red stripe/ top rot disease in Punjab.

\section{MATERIALS AND METHODS}

Isolation, purification and maintenance of the pathogen:
Diseased plants sample showing typical red stripe symptoms were collected from major sugarcane growing districts of Punjab viz., Amritsar, Jalandhar, Ludhiana and Gurdaspur in rainy season $\left(6^{\text {th }}\right.$ June to $20^{\text {th }}$ August) during 2011 and were used for isolation. The presence of the pathogen in the stripes was ascertained microscopically for the ooze from the cut ends, on a slide in a drop of sterile water. The leaf bits were surface sterilized by immersion in $0.1 \%$ mercuric chloride solution for one minute followed by washing in three changes of sterilized distilled water. After surface sterilization the leaf bits were cut in sterile water on a slide and the bacterial ooze was streaked on King's B medium in petriplates. These petriplates were then incubated for $48 \mathrm{hr}$ at $30 \pm 2^{\circ} \mathrm{C}$. Single colonies of the best growing bacterium on the King's B media were further purified and maintained by transferring it to the slants of the King's B medium at $4 \pm 2{ }^{\circ} \mathrm{C}$ and were renewed by sub-culturing at 15-20 days interval. Pathogenicity was proved following the Koch's Postulates on seventy days old plants of sugarcane variety CoJ 85.

Isolation of genomic DNA from Pathogen: Genomic DNA from four virulent isolates namely RS-2, RS-3, RS-6 and RS-8 was isolated following the method standardized by Bacteriological Lab Department of Plant Pathology. Five $\mathrm{ml}$ of liquid culture of individual isolates was incubated overnight at $25 \pm 2^{\circ} \mathrm{C}$. The culture was centrifuge for seven minutes at $10,000 \mathrm{rpm}$ in cold centrifuge (Eppendorf $5804 \mathrm{R}$ ) in $15 \mathrm{ml}$ Falcon tubes to form a cell pellet. The supernatant was discarded and 
the pellet was resuspended in $650 \mu 1$ extraction buffer by pipetting up and down repeatedly, so as to avoid foaming. The samples were then incubated at $65^{\circ} \mathrm{C}$ for 30 minutes in pre heated water bath. Cellular proteins were precipitated with $100 \mu \mathrm{l}$ of potassium acetate. Approximately equal volume $(0.7$ to $0.8 \mathrm{ml})$ of chloroform/isoamyl-alcohol was added to the lysed samples. It was mix thoroughly, and centrifuged for 5 minutes at $4^{0} \mathrm{C}$.

The upper aqueous phase containing the DNA was transferred to a new $2 \mathrm{ml}$ tube with a sterile pipette tip. To this 0.6 volume of cold isopropanol was added to precipitate the DNA. The tube was shaken back and forth until a stringy white DNA precipitate becomes clearly visible. The DNA was precipitated by centrifugation at 10,000 rpm for 10 minutes in the refrigerated centrifuge. Supernatant was discarded by carefully aspirating the isopropanol. The pelleted DNA was washed twice with $0.5 \mathrm{ml}$ ice cold $70 \%$ ethyl alcohol and centrifuged for five minutes at $10,000 \mathrm{rpm}$ so as to remove any residual salts. Pellet was collected and the left over ethanol was dried up completely by turning down micro centrifuge tubes on a blotting paper and was allowed to air dry for two hours. After that $100 \mu \mathrm{l}$ of IX TE (Tris EDTA buffer-10mM Tris HC1, 1mM EDTA, pH 8.0) was added in these tubes and the pellet was dissolved by flicking the tube. The tubes were left overnight at $4^{0} \mathrm{C}$ overnight before storing at $-20^{0} \mathrm{C}$ for further analysis.

Assessment of quantity and quality of DNA: Quantity and quality of DNA was checked by using TECAN 2000 Nanoquant Plate. The blanking was done by using $2 \mu \mathrm{l}$ of $1 \mathrm{TE}$ buffer (Tris EDTA buffer-10mM Tris $\mathrm{HC} 1,1 \mathrm{mM}$ EDTA, $\mathrm{pH}$ 8.0). The readings were taken

Table 1: Lists of primers and their sequence used for identification of isolates of Red Stripe causing bacteria.

\begin{tabular}{llll}
\hline Primer Name & Sequence 5' $\rightarrow$ 3' & Annealing temperature $\mathbf{~ ( ' C ) ~}^{\mathbf{0}}$ & Extension time (S) \\
\hline Ab-1F & CCTGCTTTGCACGCAGGAGG & 61 & 60 \\
Ab-1R & TGTGCACTTAAGCACTGTACAGCTT & 60 & 60 \\
Ab-2F & GCCTGCTTTGCACGCAGGAG & 62 & 60 \\
Ab-2R & AGCACTGTGCACTTAAGCACTGT & 60 & 60 \\
Ab-3F & CGCCTGCTTTGCACGCAGGA & 64 & 60 \\
Ab-3R & GAGCACTGTGCACTTAAGCACTGT & 60 & 60 \\
Aa-4F & AATCAGCGTTGCCGGCGGAA & 63 & 25 \\
Aa-4R & TGCCCCACTCAGAAATCTCCGGA & 62 & 25 \\
Aa-5F & GCCCGTCACACCATGGGAGC & 63 & 60 \\
Aa-5F & TGCCCCACTCAGAAATCTCCGG & 61 & 60 \\
Aa-6F & GGGGGTCGTTGGTTCGAGCC & 63 & 50 \\
Aa-6F & TTGCCCCACTCAGAAATCTCCGG & 61 & 50 \\
Aa-7F & GCCGTATCGGAAGGTGCGGC & 63 & 60 \\
Aa-7F & TGCCCCACTCAGAAATCTCCGGAT & 62 & 50 \\
SeQ 1 (Aaa) & GTCGGTGCTAACGACATGG & 60 & 40 \\
SeQ 2 (Aaa) & AGACATCTCCGCTTTCTTTCAA & 62 & 40 \\
Aaar & AATTTTTGTTGCCGACGGCAC & 62 & 40 \\
Aaaf & TCGCCTGCGGTAGGGCG & 60 & 40 \\
Aaar2 & AGAACAATTCGTCATTACTGA & 56 & 40 \\
Aaaf3 (10) & GTCATCCTCCACCAACCAAG & 62 & 40 \\
\hline
\end{tabular}

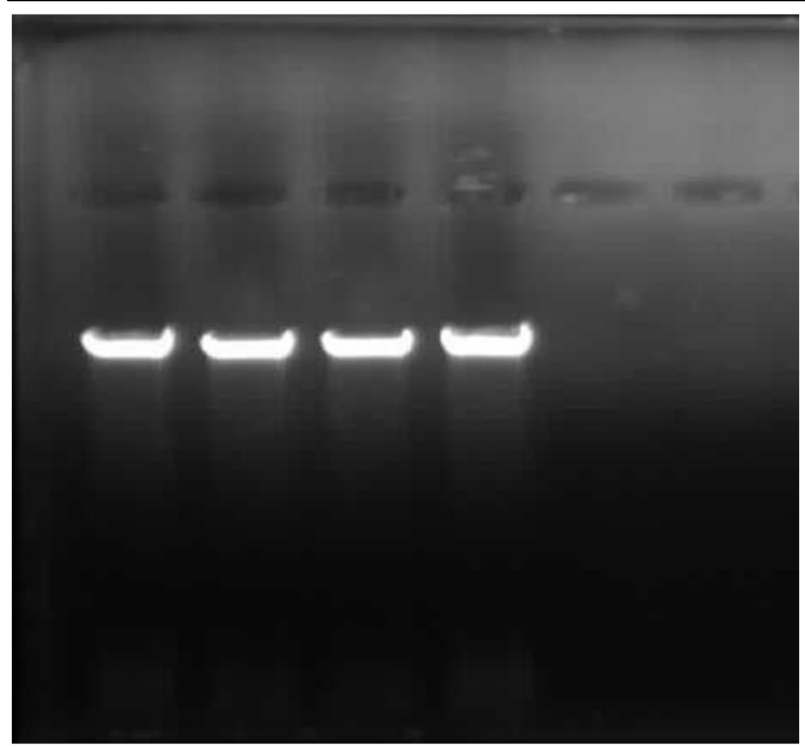

Plate 1. A single sharp band of DNA on 0.8\% Agarose gel. by dispensing $2 \mu \mathrm{l}$ of individual DNA samples from different isolates. Quality of DNA was checked at the ratio 260:280. The DNA of all the samples was diluted to $25 \mathrm{ng} / \mu \mathrm{l}$ by adding Nuclease free water and stored at $-200 \mathrm{C}$. The readings were taken thrice and average of three readings was used to make dilutions for further analysis. Alternately, DNA quality was checked on $0.8 \%$ Agarose gel. A single sharp band of DNA signified high quality of DNA.

PCR amplification: In vitro amplification using Polymerase Chain Reaction (PCR) was performed in a 96 well micro titer plate in Eppendorf Master Cycler PROS. The PCR plate was covered with thermoseal (Genexy Labs) in order to avoid evaporation and placer in a 96 well thermocycler. The final reaction volume of $30 \mu \mathrm{l}$ was prepared. Amplification was carried out at $94^{\circ} \mathrm{C}$ (Initialization) for $4 \mathrm{~min}, 94^{\circ} \mathrm{C}$ (Denaturation) for $1 \mathrm{~min}, 61^{\circ} \mathrm{C}$ (Annealing), $72^{\circ} \mathrm{C}$ (Extension step), $72^{\circ} \mathrm{C}$ (Final elongation) for $2 \mathrm{~min}$. 


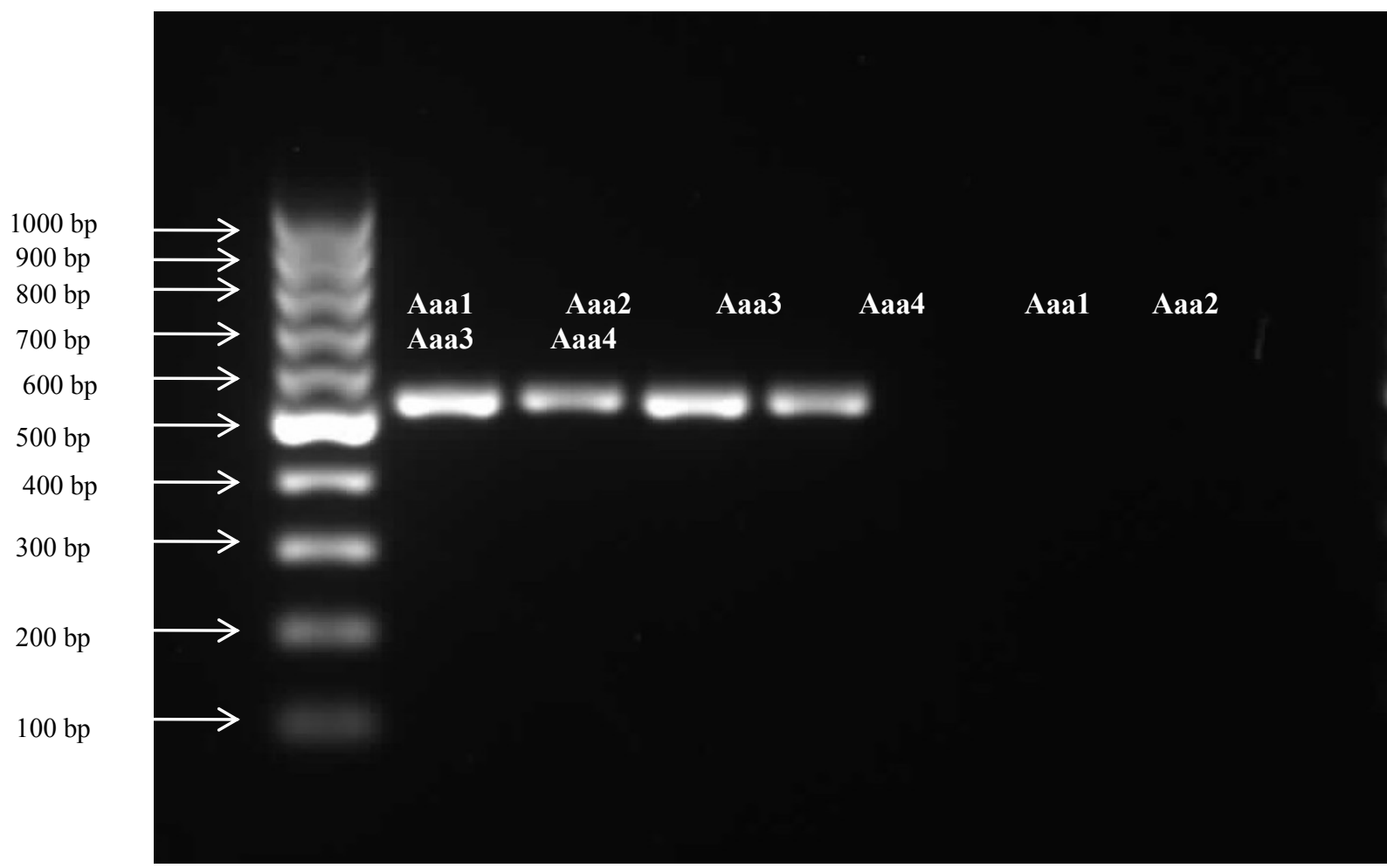

Plate 2. The amplification of the targeted ITS (Internal Transcribed Spacer) region of the rDNA of 550 base pair with primer set $\mathrm{SeQ} 1$ (Aaa), SeQ 2 (Aaa) and Aaaf3 and Aaar2.

The following sets of primer presented in table 1 were selected for the identification of the pathogen.

Visualization of PCR product: After amplif cation, $8 \mu \mathrm{l}$ of each sample was loaded in 1.5 per cent agarose gel prepared on $0.5 \mathrm{X}$ TBE buffer. PCR products were resolved by gel electrophoresis at $5 \mathrm{~V} / \mathrm{cm}$ for $3 \mathrm{hrs}$. The gels were visualized under UV light and photographed using SYNGENE gel documentation system with "Gene snap" software programme.

\section{RESULTS AND DISCUSSION}

Identification of the pathogen: The virulent isolates viz., RS-2, RS-3, RS-6 and RS-8 showing good growth were further identified by the rDNA ITS (Internal Transcribed Spacer) region amplification. After the isolation of the DNA the quality was also checked on $0.8 \%$ Agarose gel. A single sharp band of DNA was obtained which signified its high quality (Plate 1). Molecular identification was performed by using the primer set as given in Table 1, which are specific for Acidovorax avenae and Acinetobacter baumannii. Also the primer sets SeQ 1 (Aaa), SeQ 2 (Aaa) and Aaar2, Aaaf3 (used for detection of Rice Disease) which are highly specific primers for Acidovorax avenae sub sp avena were used for identification of the Red stripe causing pathogen.

It was found that all the four isolates showed the amplification of the targeted ITS (Internal Transcribed Spacer) region of the rDNA of 550 base pair with primer set SeQ 1 (Aaa) and SeQ 2 (Aaa) but the am- plification was not found with primer set Aaaf3 and Aaaf3(used for detection of Rice Disease) (Plate 2). Similarly the amplification were not found with the $A$. baumannii specific primers. Song et al. (2002) reported that the SeQ 1 (Aaa) and SeQ 2 (Aaa) reacted with all the strains of $A$. avenae subsp avenae originating from sugarcane, foxtail, oat, corn, rice and millet. Song et al. (2004) further reported that the nested PCR assay produced the expected DNA product from 58 rice strains tested but not with DNA from 27 strains of $A$. avenae subsp avenae from sugarcane, corn and other hosts. Similarly, Fontana et al. (2016) through genome sequence reported that the organism associated with red stripe disease of sugarcane as Acedovorax avenae in Argentina. Furthermore they reported the draft genome of the $A$. avenae T10_61 strain contain $5,646,552 \mathrm{bp}$ and $\mathrm{G}+\mathrm{C}$ content of $68.6 \mathrm{~mol} \%$.

\section{Conclusion}

The present experiment was conducted with a view to identify the associated organism with the red stripe/ top rot disease of sugarcane in Punjab. For this different sets of genus and species specific primers were used for identification of the pathogen. It was found that all the isolates showed the amplification of the targeted ITS (Internal Transcribed Spacer) region of the rDNA of 550 base pair with primer set SeQ 1 (Aaa) and SeQ 2 (Aaa). Our studies confirmed the causal organism of the red stripe / top rot disease of sugarcane in Punjab (India) districts as Acidovorax 
avenae sub sp avenae.

\section{REFERENCES}

Anonymous. (2015). Department of Agriculture, Government of Punjab. http://agripb. gov. in/home. Php page $=$ sugar

Chona, B.L. and Rao, Y.P. (1963). Association of Psedomonas rubrilineans ( Lee et al) Stapp. With the red stripe disease of sugarcane in India. Indian Phytopathology 16, 392-93.

Fontana, P.D., Fontana. C.A., Bassi. D., Puglisi. E., Salazar. S.M., Vignolo. G.M., Coccocelli. P.S. (2016) Genome Sequence of Acidovorax avenae Strain T10_61 Associated with Sugarcane Red Stripe in Argentina. Genome Announcement 4:4(1), pii: e01669-15. doi: 10.1128/ genomeA. 01669-15.

Lee, H.A. Purdy, H.A., Barnum, C.C., and Martin, J.P. (1925). A comparison of red stripe disease with bacterial diseases of sugarcane and other grasses. Red Stripe Disease Studies. Experiment station Hawaii Sugarcane
Planters Association Path Deptt 64-74.

Lyon, H.L. (1922). A leaf disease of the Tip cane Proc Hawaiian Sugar Planters Association : 246.

McRae, W. and Desai, (1933). New diseases reported during the year 1932 International Bulletin Plant Protection 7, 79-80.

Song, W.Y., Kim H.M. and Schaad, N.W. (2002). PCR primers for detection and identification of plant pathogenic species, subspecies and strains of Acidovorax. U.S. Patent, 6423499.

Song, W.Y., Kim, H.M., Hwang, C.Y. and Schaad, N.W. (2004). Detection of Acidovorax avenae ssp. avenae in rice seeds using BIO-PCR Journal of Phyotopathology 152, 667-76.

plant pathogenic species, subspecies and strains of Acidovorax. U.S. Patent, 6423499.

Song, W.Y., Kim, H.M., Hwang, C.Y. and Schaad, N.W. (2004). Detection of Acidovorax avenae ssp. avenae in rice seeds using BIO-PCR Journal of Phyotopathology, $152,667-76$. 